\title{
The Arctic in Russia's Emergency Preparedness System
}

\author{
Ingvill Moe Elgsaas \\ Norwegian Institute for Defence Studies (IFS)
}

\begin{abstract}
Recent and projected developments in the Arctic call for improving emergency preparedness in the region. Arctic emergency preparedness is facing traditional challenges on a new scale as well as new, non-traditional challenges. There is political will on the part of Russian leadership to create a comprehensive emergency preparedness system in the Arctic, a system that integrates non-traditional alongside traditional emergency preparedness. This paper examines the formal institutional foundation for developing an emergency system in the Russian Arctic that includes counterterrorism as well as search and rescue and oil spill response. The paper concludes that the strengthening of Russian counterterrorism in recent years has produced a parallel specialized structure that operates autonomously and in isolation from the emergency preparedness structures responsible for handling traditional challenges. Differences between the national system for countering terrorism and the unified state system for prevention and liquidation of emergencies hinder comprehensive emergency preparedness in the Russian Arctic. That being said, there is considerable overlap in central actors between the two systems. This may serve as a window of opportunity for cooperation in Arctic emergency preparedness.
\end{abstract}

Keywords: counterterrorism; search and rescue; oil spill response; High North

Responsible Editor: Øyvind Ravna, UiT - The Arctic University of Norway, Tromsø, Norway.

Received: January 2018; Accepted: November 2018; Published: December 2018

\section{The Arctic: Great Promise - Great Danger}

The Russian Arctic holds many and varied resources, and Russia has ambitious plans for utilising them. According to Russia's Arctic Policy, the Arctic should secure the country's supply of hydrocarbons, biological resources and other raw materials,

\footnotetext{
^Correspondence to: Ingvill Moe Elgsaas, email: ingvill.elgsaas@ifs.mil.no

(C) 2018 Ingvill Moe Elgsaas. This is an Open Access article distributed under the terms of the Creative Commons Attribution-NonCommercial 4.0 International License (https://creativecommons.org/licenses/by-nc/4.0/), allowing third parties to share their work (copy, distribute, transmit) and to adapt it, under the condition that the authors are given credit, that the work is not used for commercial purposes, and that in the event of reuse or distribution, the terms of this license are made clear.

Citation: Ingvill Moe Elgsaas. "The Arctic in Russia's Emergency Preparedness System.” Arctic Review on Law and Politics, Vol. 9, 2018, pp. 287-311. http://dx.doi.org/10.23865/arctic.v9.1131
} 
and the Arctic Zone of the Russian Federation should become Russia's main base for strategic resources by $2020 .{ }^{1}$ The Northern Sea Route should be developed as an alternative route for Eurasian transit, ${ }^{2}$ a prospect that could - in the long run prove decisive for international shipping with accompanying geopolitical ripple effects. There have been bouts of increased economic and military activity in the Russian Arctic. A case in point is the Yamal LNG Project with the production and shipping of liquefied natural gas from Sabetta in Yamalo-Nenets. Another is the building and reopening of military bases along the Arctic coast from the "Arctic Shamrock" on Aleksandra Land (Franz Josef Land) in the West to the "Northern Clover" on Kotelnyy Island (Novosibirsk Archipelago) in the East. The timeline for Russia's plans for the Arctic is highly unrealistic; current obstacles to further development of off-shore oil and gas deposits simply serve to underscore the overly ambitious nature of such plans. In a long term perspective, however, Russia will probably manage to carry out some of its plans.

More activity in the Arctic means that the region is facing new challenges as well as traditional challenges on a new scale. Traditional challenges are first and foremost to ensure adequate search and rescue (SAR) and oil spill response (OSR) in an inhospitable and remote corner of the world. A non-traditional challenge in the Arctic is counterterrorism (CT). Arctic counterterrorism is a new issue and, arguably, one that is particularly testing. Stretching limited resources across vast territory that requires especially costly equipment due to its climate is a well-known challenge for activities in the Arctic. The nascent field of Arctic counterterrorism must also grapple with the fact that it is a trendy but tardy addition to the emergency preparedness agenda in the region. Despite these and other asymmetries between Arctic SAR, Arctic OSR and Arctic CT, there is will on the part of Russian leadership to create a comprehensive emergency preparedness system in the Arctic that includes counterterrorism alongside traditional emergency preparedness.

Creating a comprehensive emergency preparedness system (sistema kompleksnoy bezopasnosti) to protect the territory, people and critical entities in the Arctic from emergencies (natural and man-made) is among the tasks laid down in Russia's Arctic Policy. ${ }^{3}$ Speaking to the Russian Security Council on the topic of implementing state policy in the Arctic, President Vladimir Putin highlighted terrorism among potential threats that must be countered to ensure comprehensive emergency preparedness in the Arctic. ${ }^{4}$ Including terrorism among potential challenges in the Arctic is not as farfetched as it may appear at first glance. There is a well-documented preference among terrorists to target energy facilities. ${ }^{5}$ This feeds concerns that Arctic energy facilities may become targets. In his speech to the Russian Security Council, President Putin emphasised that oil and gas facilities, loading terminals, and pipelines must be adequately protected from terrorists and other potential threats. ${ }^{6}$ Commenting on Russia's counterterrorist effort in the Arctic, Head of the Federal Security Service and of the National Antiterrorism Committee, Aleksandr Bortnikov, observed that it "has some faults, especially in ensuring the security of the Northern Sea Route and 
maritime based economic enterprises". ${ }^{7}$ Bortnikov has called for improved regulation to protect assets in the Arctic, with particular mention of Russia's icebreaker fleet, maritime drilling rigs and underwater facilities as well as Northern Sea Route infrastructure. ${ }^{8} \mathrm{~A}$ testament to Russia's attention to potential terrorist threats in the Arctic is regular counterterrorism exercises in the region. Many of these exercises involve scenarios where "terrorists" target shipping and energy facilities. ${ }^{9}$

Addressing complex and developing threats to safety and security in the Russian Arctic comprehensively is a commendable aim. Creating a comprehensive system that covers this vast territory and that covers emergency preparedness fields with highly different "footprints" in the Arctic is no straightforward matter. Strategic documents tend to be rife with good intentions that may or may not translate into action. We are right to question whether Russia's comprehensive emergency preparedness system may end up in the list of good, but unrealised, intentions. For one thing, traditional emergency preparedness has been on the agenda for a long time already, yet there are no explicit plans as to how existing systems will relate to, merge with, integrate in or be replaced by a new comprehensive system. Empirically, it appears that a comprehensive emergency preparedness system is set to develop organically and incrementally without overarching reforms. This ad hoc approach places much of the strain on the collective of individual systems; and specifically on their ability to rise to the challenge and, in some form or another, come together in the name of comprehensive emergency preparedness in the Arctic. The research question this article seeks to answer is this: Are SAR, OSR and CT structures in the Arctic conducive to comprehensive emergency preparedness in the region? Answering this question furthers our knowledge about the Arctic as a region in Russia's emergency preparedness system(s), and allows us to assess the structural foundation for a comprehensive emergency preparedness system that covers traditional and untraditional challenges in the Russian Arctic.

In order to answer the research question, this study uses the comparative method. This method helps us identify similarities and difference among the three fields' structures that can affect the overarching structure, the architecture, of comprehensive emergency preparedness in the Arctic. The comparative method is flexible as regards subject matter and sources. Case studies of the various fields' structures can therefore be highly informative in and of themselves. In order for the comparisons to yield insights in a more structured manner, this study pays particular attention to a few organisational principles: vertical/horizontal organisations, territorial or functional organisations, and centralised/decentralised decision-making. In order to discuss potential effects of the similarities and/or differences among the various structures, this study makes use of a typology for diversity that includes predicted outcomes for various types and degrees of similarity/difference. These are presented in the next section. The study makes use of various sources. The main sources of information are the official documents that describe and prescribe the emergency preparedness structures under study. These documents were sourced from official 
channels and legal databases. The study also makes use of information issued by the various actors involved in emergency preparedness. Lastly, the study supplements these primary sources with secondary sources.

The paper argues that there are significant structural hindrances to integrated emergency preparedness in the Russian Arctic. On the one hand, there are multiple and varied SAR and OSR systems in place. This complicates coordination among a large number of actors involved in these activities. On the other hand, there is a simple and symmetrical CT system in place that facilitates coordination among the many actors involved in this field. While responsibility for coordinating CT rests with one actor, responsibility for SAR and OSR activities are divided among several different coordinating and managing actors with diffusely delineated areas of responsibility. That said, there is opportunity for cooperation and flexibility in the architecture of Russia's Arctic emergency preparedness, as well as potential for internal competition. Involvement of many different actors is a feature SAR, OSR and $\mathrm{CT}$ all have in common. What is more, in many cases, it is also the very same actors that are involved. This, the paper argues, may prove helpful to promote comprehensive emergency preparedness in the Russian Arctic.

In the next section, we will flesh out the scope of the analysis and present the analytical tools. Section 3 discusses SAR and OSR. Section 4 discusses CT. Section 5 discusses the architecture of emergency preparedness in the Russian Arctic based on the preceding sections. Section 6 concludes.

\section{Structures and Architecture}

The topic of this paper can be summed up as a study of the architecture of Russia's emergency preparedness in the Arctic. "Architecture" here refers to the composite structure (the super-structure) that emerges when the structures of the three emergency preparedness fields are considered together. Structure is one of two dimensions, for lack of a better word, that make up a system. The other dimension is practice (informal institutions) and will not be considered here. This sole focus on structure should in no way be interpreted as a claim that practice is unimportant. Practice is important in its own right; and, to fully understand systems, it is also important to analyse the interaction between structure and practice. That we here analyse structure, rather than practice or both structure and practice, has both analytical and practical motives. A comprehensive emergency preparedness system that transcends the traditional fields of emergency preparedness in the Arctic is a novel and under-analysed topic. It is also a big topic and its analysis ought to be operationalised sequentially. Since formal institutions set the scope for informal institutions (through their shortfalls well as in positive terms), it is appropriate to analyse structure in the first instance. Furthermore, to study practice requires the use of alternative sources, such as, ideally, the practitioners themselves. Access to such sources is limited. Counterterrorism is a particularly sensitive topic in this regard. This serious 
challenge affects analyses of practice, but it does not impede us from furthering our understanding of the SAR, OSR and CT structures and the architecture of Russia's emergency preparedness in the Arctic.

In order to discuss whether the architecture in place is conducive to achieve the stated goal of comprehensive emergency preparedness, it will benefit us to lay down a few organisational principles that we can work with: vertical/horizontal organisations, territorial or functional organisations, and centralised/decentralised decision-making. These principles can aid our understanding of the emergency preparedness structures and how they come together in the architecture of Arctic emergency preparedness.

Vertical/horizontal organisations. Structures can vary in terms of how tall or flat they are. Tall structures are characterised by middle-management that separates the top of the structure, say the emergency preparedness leadership, from the bottom of the structure, emergency personnel. In flat structures, on the other hand, there is less distance between the leadership at the top and the practitioners at the bottom. How tall or flat a structure is thus does not depend on the number of units on its levels but on the number of levels. As a rule of thumb, we will here consider any structure with 1-2 levels as flat and any structure with 5 or more levels as tall, while structures with 3-4 levels are considered moderate on the vertical/horizontal continuum.

Territorial or functional organisations. Structures can be organised territorially or functionally. Say we have countries A and B that each has three regions 1, 2 and 3 and that are both in the process of institutionalising search and rescue, oil spill response and counterterrorism, incidentally. Country A introduces a territorial structure with regional preparedness organisations in each of regions 1, 2 and 3 that handle the three fields. Country B opts for a functional structure with a search and rescue organisation, an oil spill response organisation and a counterterrorism organisation each with regional branches in 1,2 and 3.

Centralised/decentralised decision-making. The degree of centralisation or decentralisation of a structure can be reflected in its degree of vertical/horizontal organisation, but not necessarily. Regardless of how tall or flat a structure is, there is still a degree of flexibility as to how centralised or decentralised its decision-making is. Where decision-making sits and the degree of centralisation/decentralisation in decision-making can have significant effects on a structure's ability to coordinate efforts. In line with this study's topic, we treat decision-making only in terms of where in the structure decision-making competencies are concentrated or whether they are dispersed - without venturing to evaluate the practice of decision-making.

We here deal with ideal types and reality seldom does us the favour of displaying ideal types, so we shall use these different types as inspiration to tease out how the emergency preparedness structures compare rather than use them as blueprints for 
identification. It is also necessary to reflect on how we should interpret differences and similarities among the emergency preparedness structures and diversity within the architecture of Arctic emergency preparedness. In this respect we can make use of David Harrison and Katherine Klein's diversity typology that operationalises diversity as separation, variety or disparity in organisations. ${ }^{10}$ The three types of diversity are cross-tabulated with the amount of diversity: minimum, moderate and maximum. The minimum categories in the typology capture similarities while the moderate and maximum categories capture degrees of difference. Separation captures diversity in positions along a single continuous attribute - in our case, the vertical/horizontal continuum. Variety captures diversity in categorical attributes -- in our case, territorial or functional organisation. Disparity captures diversity in amount or proportion of a socially valued or desired resource - in our case, decision-making. These three diversity types are commonly associated with different outcomes. Separation can reduce cohesiveness and decrease task performance. Variety can foster greater creativity, innovation, flexibility, and decision-quality, as well as task conflict. Disparity can lead to internal competition, reduced member input and withdrawal. ${ }^{11}$ By coupling the organisational principles and the diversity typology, we can take our comparative analysis of the emergency preparedness structures a step further. Beyond observing similarities and differences among the emergency preparedness structures; we can discuss diversity in the architecture of Arctic emergency preparedness and potential outcomes.

Before we turn to the emergency preparedness structures, we shall spare a few words to lay out how Russia itself is structured, and where the Russian Arctic sits within this structure. As a federation, Russia's state power is divided between two levels: the federal and regional levels. On the regional level there are more than 80 entities, the regions or federal subjects -- which is the formal Russian term. The regions are again subdivided into numerous municipalities, the local level. Since 2000, the regions have been grouped together into super-regions, the federal districts, of which there are now eight. The Russian Arctic is not a clearly delineated area, but generally refers to all Russian territory north of the Arctic Circle. The Arctic Zone of the Russian Federation on the other hand, is a clearly defined land area that consists of a selection of regions and municipalities belonging to four different federal districts. ${ }^{12}$ This zone was created in 2014 in relation to the Russian government's launch of a state programme for "Socio-economic development of the Arctic Zone of the Russian Federation until 2020" ${ }^{13}$ The Arctic zone is thus not a super-region like the federal districts; however, it is an area with particular needs and challenges that have resulted in a targeted state programme. While the Arctic zone benefits from being clearly demarcated, it is a distinct drawback that it only covers land territory and not the Arctic seas. Emergency preparedness at sea is an important part of Arctic emergency preparedness. I therefore use the less precise 
term Russian Arctic so as not to exclude the maritime domain in this treatment of the Arctic in Russia's emergency preparedness.

\section{Search and Rescue and Oil Spill Response in the Russian Arctic}

SAR and OSR both fall within Russia's unified state system for prevention and liquidation of emergencies (Rossiyskaya edinnaya gosudarstvennaya sistema preduprezhdeniya i likvidatsii chrezvychaynykh situatsiy, RSChS). The RSChS is a complex and loosely defined system that includes managing bodies, forces and resources belonging to federal and regional executive bodies, local self-governing bodies and organisations that deal with questions pertinent to the protection of people and territory from emergencies. ${ }^{14}$ The system functions on five levels: federal, interregional, regional, municipal and object. There are managing bodies on each level including coordinating bodies, permanent management bodies and day-to-day management bodies. ${ }^{15}$ The RSChS has both territorial and functional subsystems. The territorial subsystems are formed in each region (federal subject) and unite the RSChS bodies operating on a region's territory. Among Russia's many regions, there are eight whose land territories have been included in the Arctic Zone of the Russian Federation -- either fully or in part: Murmansk, Arkhangelsk, Nenets, Komi, Yamalo-Nenets, Krasnoyarsk, Sakha and Chukotka (Figure 1). With the exception of Komi, which is landlocked, these regions also command Russia's Arctic coast. As an example of what the territorial subsystems in the RSChS look like, we will take a look at the regional emergency preparedness system in the Murmansk Region.

Murmansk is located in the Northwestern Russian Arctic and is the gatekeeper for access further into the Russian Arctic and to the Northern Sea Route from the West. Due to favourable climatic conditions, the region is easily accessible and welldeveloped relative to its Arctic location, and it plays a central role in developing the Russian Arctic. The Murmansk regional emergency preparedness system is led by the Main Directorate of Russia's Ministry for Emergencies for the Murmansk Region (Glavnoye upravleniye MChS Rossii po Murmanksoy Oblasti). This body was set up in 2005 and oversees a long list of emergency preparedness bodies in the region. ${ }^{16}$ The relationship between the various bodies in this territorial system is somewhat unclear. For example, SAR formations, including the Murmansk Arctic Complex Emergency Rescue Centre in Kirovsk, are listed as one of 13 headings in the Main Directorate's overview of its 'forces and resources' ${ }^{17}$ These same SAR formations also appear as subordinate bodies under one of the other headings in the list, that of the territorial fire and rescue garrison of the Murmansk Region. ${ }^{18}$ Many of the bodies under the Main Directorate are firefighting bodies. There are no designated OSR bodies listed among the Main Directorate's bodies. 

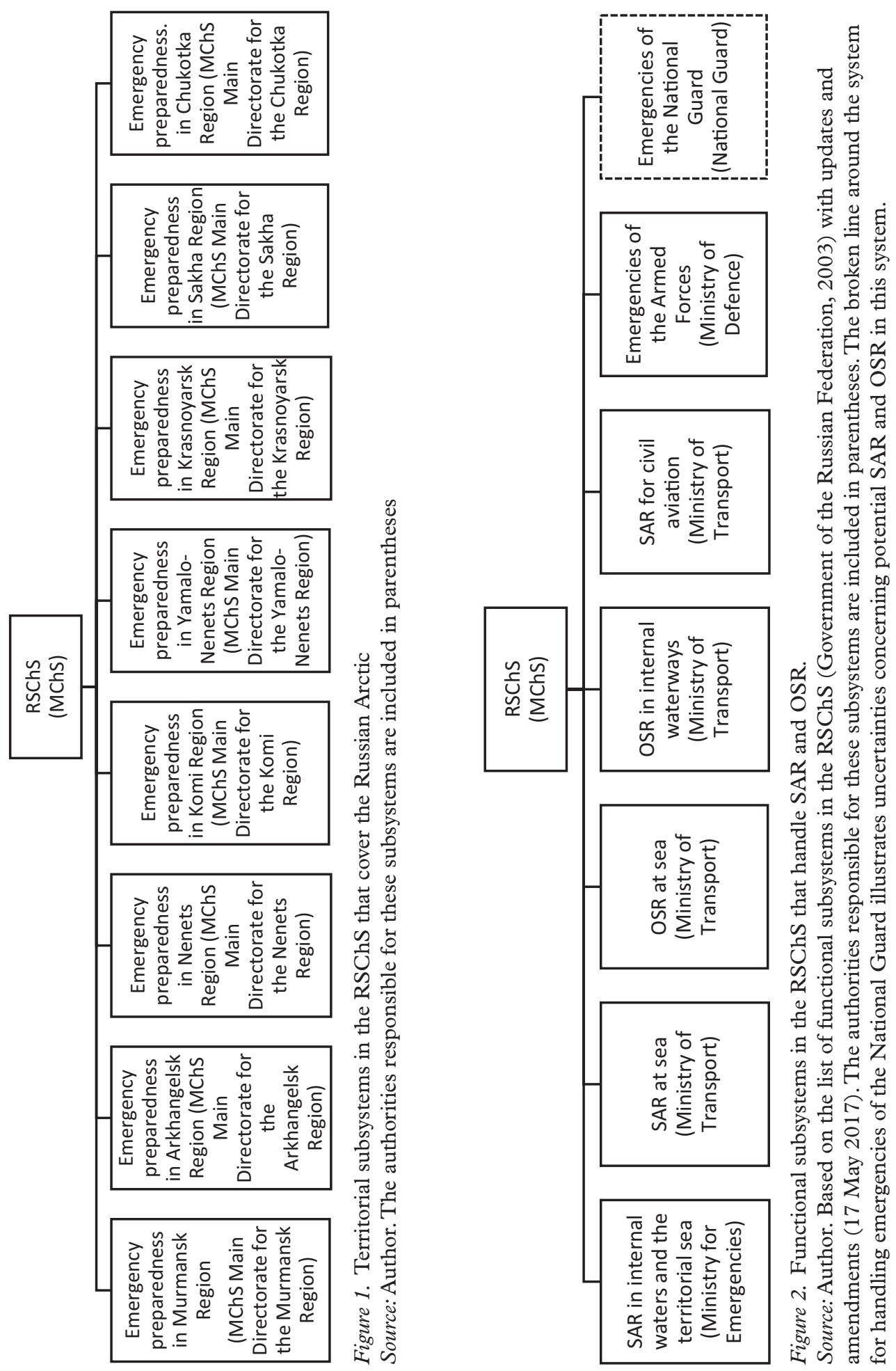
Turning to the functional subsystems, the RSChS has 44 such subsystems. These include SAR in internal waters and the territorial sea, SAR at sea, OSR at sea, OSR in internal waterways, and SAR for civil aviation (Figure 2). ${ }^{19}$ The Ministry of Emergencies $(\mathrm{MChS})$ is responsible for SAR in internal waters and the territorial sea (sometimes referred to as "SAR on land"), and the Ministry of Transport is responsible for SAR at sea, OSR at sea, OSR in internal waterways, and SAR for civil aviation. In addition to the functional subsystems that explicitly address SAR and OSR there is at least one other relevant functional subsystem in the RSChS. The Ministry of Defence is responsible for a subsystem that handles all emergencies pertaining to the Armed Forces of the Russian Federation. The Russian Navy's Northern Fleet is a central participant in emergency preparedness in the Arctic and it is therefore appropriate to include this subsystem here. Another subsystem has recently been added to the RSChS, a subsystem for emergencies pertaining to the National Guard's troops. This system may also involve SAR and OSR, but a lack of information makes it difficult to assess at present.

We now turn to the organisation of these functional subsystems. The discussions are organised according to the responsible authorities, starting with the Ministry for Emergencies in section 3.1. Section 3.2 looks at the functional subsystems belonging to the Ministry of Transport. Section 3.3 looks at military SAR and OSR, with a focus on the Ministry of Defence and with cursory observations about the National Guard.

\subsection{Ministry for Emergencies}

The Ministry for Emergencies (MChS) is responsible for SAR in internal waters and the territorial sea. The organisation of this system is presented in the "Provision on the Functional Subsystem for SAR in Internal Waters and the Territorial Sea of the Russian Federation in the RSChS" ${ }^{20}$ In line with the general stipulations for the $\mathrm{RSChS}$, the system for SAR in internal waters and the territorial sea is organised into five levels with coordinating bodies, permanent management bodies and bodies responsible for the day-to-day management. The MChS is also responsible for the overall coordination of the RSChS itself, as well as being responsible for several other functional subsystems. The ministry carries out its responsibilities through its network of territorial divisions as well as specialised bodies. On the regional level, MChS' territorial divisions follow the country's territorial-political structure (the federal subjects). The interregional level deviates from the federal districts and instead groups the federal subjects into four emergency preparedness regions: Siberia, South, Central and Northwest. ${ }^{21}$

The MChS has a specialised SAR service that is organised into eight regional SAR detachments, which correspond with the federal districts, and 38 branches. The MChS' SAR service also has a central rescue service, "Tsentrospas", and specialised units, including an Arctic rescue research and training centre, "Vytegra". In 
addition to "Vytegra" (located outside the Arctic in Andomskoye, Vologda Region), the $\mathrm{MChS}$ has five Arctic rescue centres: Vorkuta Arctic Integrated Emergency Rescue Centre, Murmansk Arctic Emergency Rescue Centre (based in Kirovsk), Nenets Arctic Emergency Rescue Centre (based in Naryan-Mar), Arkhangelsk Arctic Emergency Rescue Centre, and Dudinka Arctic Emergency Rescue Centre. All these centres belong to the Northwestern SAR detachment, except for the Dudinka centre that belongs to the Siberian SAR detachment. ${ }^{22}$ As part of Russia's ongoing drive to expand activities in the Arctic, there is an ambition to open $10 \mathrm{MChS}$ rescue centres along the Arctic coast. Initially, the 10 centres were to be opened by 2015 but due to lack of funding the time frame has been extended to 2020. It is not altogether clear how these 10 centres relate to the centres presented above, as lists of the 10 "new" SAR centres include some but not all of the MChS' existing SAR centres. For example, in December 2016, it was reported that four out of 10 centres are operational: Murmansk, Arkhangelsk, Naryan-Mar and Dudinka. ${ }^{23}$ Much hope is pinned on these centres to increase emergency preparedness in the Russian Arctic. However, even before they are operational, analysts are questioning if these centres, should they all become operational, will be enough to bring the Northern Sea Route up to the level of international safety standards. ${ }^{24}$ These rescue centres illustrate both a drive to improve emergency preparedness in the Russian Arctic, as well as its limitations, including financial restraints, which underscores the importance of comprehensive emergency preparedness in the region.

\subsection{Ministry of Transport}

The Ministry of Transport is responsible for six functional subsystems in the RSChS. Four of these include either SAR or OSR: SAR at sea, OSR at sea, OSR in internal waterways, and SAR for civil aviation..$^{25}$ A Ministry of Transport subsidiary is responsible for the three subsystems covering the sea and internal waterways, the Federal Agency for Marine and River Transport (Rosmorrechflot). Another Ministry of Transport subsidiary is responsible for SAR for civil aviation, the Federal Air Transport Agency (Rosaviatsiya).

Rosmorrechflot is responsible for SAR and OSR at sea as well as OSR in internal waterways. The provisions on the two functional subsystems for SAR and OSR at sea describe similar organisations, but whereas the provision for SAR presents two levels (federal and regional), the provision for OSR at sea presents three levels (federal, regional and object). ${ }^{26}$ Rosmorrechflot coordinates both systems through its Commission for prevention and liquidation of emergency situations and fire safety. Rosmorrechflot's Operative staff for prevention and liquidation of emergency situations and fire safety is listed as the system's managing body. A Rosmorrechflot subsidiary, the State Maritime Emergency and Rescue-coordination Service (Gosmorspassluzhba) is identified as the system's permanent management body. Gosmorspassluzhba operates a central State Maritime Rescue-coordination Centre (federal level); regional maritime rescue coordination centres, maritime rescue sub-centres, basin 
emergency rescue administrations (BASU) and administrations for emergency rescue and underwater engineering work (all on the regional level). Additionally, for OSR at sea, permanent management bodies on the object level are duty and dispatch services of maritime transport organisations, ports, Rosmorport's branches, shipping companies and other organisations that engage in prospecting for, or the production, processing, transportation or storage of oil at sea. ${ }^{27}$ According to Gosmorspassluzhba's webpage, the service has nine branches, including a "Northern branch" located in Murmansk and an "Arkhangelsk branch". The service operates a number of rescue coordination centres, including a regional rescue coordination centre in Murmansk and a maritime rescue sub-centre in Arkhangelsk. There is also a basin emergency rescue administration in Murmansk with a branch in Arkhangelsk. According to Gosmorspassluzhba, the service and its branches and rescue coordination centres make up the RSChS' functional subsystems for responding to emergencies relating to SAR and OSR at sea. ${ }^{28}$

Rosmorrechflot is also responsible for OSR in internal waterways. The relevant provision was adopted in $2016 .{ }^{29}$ This system operates on three levels: federal, regional (basin) and object, and is coordinated by commissions on prevention and liquidation of emergencies and ensuring fire safety. Rosmorrechflot's commission is on the federal level, the administrations for internal water basins' commissions is on the regional level and "relevant organisations" are on the object level. ${ }^{30}$ The permanent management bodies are Rosmorrechflot, the administrations for internal water basins, and structural divisions of organisations engaged in prospecting and exploration, extraction, processing transportation, transshipment, bunkering, or storage of oil and petroleum products and organisations authorised to carry out OSR. Day-today management is carried out by the duty service of the Rosmorrechflot and Gosmorspassluzhba on the federal level, and by the duty service of the administrations for internal water basins on the regional level. On the object level, this responsibility rests with the duty-dispatch services of the organisations engaged in the above listed activities. Throughout the provision on OSR in internal waterways, Rosmorrechflot is referred to simply as "the competent body", a term which does little to facilitate quick and unambiguous communication with the reader.

OSR in internal waterways is the last of the functional subsystems to be operationalised and it challenges established truths in Russia's emergency preparedness. It has been customary to describe the emergency preparedness system as consisting of a sea component and a land component, with the Ministry of Transport responsible for SAR and OSR at sea and the Ministry of Emergencies responsible for SAR and OSR on land. Hence the reference to MChS' SAR in internal waters and the territorial sea as "SAR on land". Following this logic, OSR in internal waterways should be "OSR on land" and should figure among the MChS' responsibilities. What is more, there is consensus among scholars and practitioners that SAR and OSR at sea and SAR and OSR on land operate independently of one another. ${ }^{31}$ The jury is out as to what practical consequences it has that "OSR on land" has been allocated to the 
authorities traditionally in charge of the sea component. This raises serious questions about where we draw the lines of responsibility between the different systems. This is also interesting in light of the observation that a focus on the sea component of Arctic OSR appears to have side-lined the land component. ${ }^{32}$

The matter of unclear lines of responsibility does not just pertain to OSR, but also to SAR in the Russian Arctic. According to Viktor Ilyukhin, the many actors involved in Russian SAR perform similar tasks and often in the same area with resulting SAR preparedness being insufficient. ${ }^{33}$ Poor coordination of SAR resources means, according to Ilyukhin, that it is easier for the regional rescue coordination centre in Murmansk to receive airborne assistance from Norway than it is to get Russian aircrafts in the air. ${ }^{34}$ There is a plan for SAR cooperation, the Plan for Cooperation among Federal Executive Bodies when undertaking Search and Rescue Activities at Sea and in Water Basins of the Russian Federation. ${ }^{35}$ According to this plan, the MChS coordinates SAR activities while both the MChS and the Ministry of Transport organise work in their respective areas of responsibility. It further states that the MChS and the Ministry of Transport participate in SAR activities alongside the Ministry of Defence, the Ministry of Environmental Protection and Natural Resources $^{\star}$, the Ministry of Fuel and Energy ${ }^{\star}$, the Federal Fisheries Committee ${ }^{\star}$, the Federal Border Service ${ }^{\star}$, and the Russian Academy of Sciences. The Ministry of the Interior, the Ministry of Health and Medical Industry ${ }^{\star}$, the Ministry of Communications ${ }^{\star}$, and the Federal Service for Hydrometeorology and Environmental Monitoring supply support resources. Organising SAR training and exercises is the responsibility of the MChS (in water basins) and the Ministry of Transport (at sea). As illustrated by the defunct titles (marked by ${ }^{\star}$ ), the plan for SAR cooperation is not a living document. There is no equivalent plan for cooperation in OSR. Outdated regulation does little to alleviate the unclear relationship between and within the systems. An illustrative example of outdated regulation is provided by Alexey Bambulyak, Are Sydnes and Maria Sydnes' survey of key legislative documents regulating OSR activities in Russia. ${ }^{36}$ Solving these organisational and regulatory idiosyncrasies of SAR and OSR falls beyond the scope of this paper and so we must content ourselves with these observations for the time being, and turn our attention to the fourth functional subsystem of the Ministry of Transport.

Rosaviatsiya is responsible for the unified system for aerospace search and rescue in the Russian Federation (edinaya sistema aviatsionno-kosmicheskogo poiska $i$ spaseniya $v$ Rossiyskoy Federatsii), aerospace SAR. Aerospace SAR is organised into zones that correspond to the zones in the unified system for air traffic management. ${ }^{37}$ Four zones cover the Russian Arctic and several regional SAR bases are located in the Arctic: Murmansk, Arkhangelsk, Naryan Mar, and Vorkuta in the Northwestern aerospace SAR zone; Salekhard in the Urals aerospace SAR zone; Khatanga and Norilsk in the Siberian aerospace SAR zone; and Tiksi and Anadyr in the Far Eastern aerospace SAR zone. ${ }^{38}$ Aerospace SAR is organised on three levels: federal, 
regional and local. Managing bodies are presented somewhat differently in the provision on the aerospace SAR system approved by the Russian government in 2007, and in the provision on aerospace SAR as a functional subsystem approved by the Ministry of Transport in 2012. According to the former, aerospace SAR has leading (rukovodyashchie) bodies on the federal and regional levels (Rosaviatsiya and its territorial bodies) and operative bodies on the federal, regional and local levels (the Main Aviation Coordination Centre for SAR, aviation coordination centres for SAR, and flight control authorities). ${ }^{39}$ According to the description of this system as a functional subsystem in the RSChS, there are coordinating bodies, permanent management bodies, and bodies responsible for the day-to-day management on all three levels. ${ }^{40}$ The governmental and ministerial provisions are both in effect. This example serves to illustrate a point that affects the RSChS more generally. It seems that an array of emergency preparedness systems have been "rounded up" and included in the RSChS without explicitly addressing their structures that do not conform to the prescribed structure of the RSChS.

\subsection{Military SAR and OSR}

The Ministry of Defence is responsible for the RSChS' functional subsystem for prevention and liquidation of emergencies of the Armed Forces of the Russian Federation. ${ }^{41}$ It is understood that the Ministry of Defence's responsibilities for handling emergencies also extend to security related entities outside of the Armed Forces. According to Viktor Ilyukhin (who refers to the Russian Maritime College), the Ministry of Defence is responsible for organising SAR to recover air and sea vessels belonging to the Federal Security Service (FSB) and the Ministry of Internal Affairs, as well as those belonging to the Ministry of Defence itself. ${ }^{42}$ Since the time of Ilyukhin's writing, many of the Ministry of Internal Affairs' forces have been transferred to the National Guard (more on this below).

Military activities in the Arctic are concentrated in the Northern Fleet based on the Kola Peninsula in the Northwestern Russian Arctic. The Northern Fleet is the centrepiece in the new "Arctic military district" (Joint Strategic Command "North") that became operational 1 December 2014. The Northern Fleet's HQ is located in Severomorsk (Murmansk Region), one of 11 locations listed as the main bases for the Russian Navy's SAR system (sistema poiskovo-spasatelnogo obespecheniya Voenno-Morskogo Flota). ${ }^{43}$ The only other Arctic location in the list is Severodvinsk (Arkhangelsk Region), another base of the Northern Fleet. The command of the Navy SAR system is as follows: the Navy General Staff (Navy SAR Service) in Saint Petersburg; the fleet headquarters (fleet SAR administrations) including Severomorsk (Northern Fleet); headquarters of formations (formations' SAR services) including the White Sea naval base in Severodvinsk (Northern Fleet); and administrations and staffs of naval aviation units and formations. ${ }^{44}$ This four-level SAR structure adheres to the Navy's structure and command. 
The Navy's SAR system is an integral part of the functional subsystem in the RSChS for prevention and liquidation of emergencies of the Russian Armed Forces. This effectively makes Navy SAR a sub-subsystem in the RSChS. It is reasonable to assume that there may be more Navy SAR capacities present in the Russian Arctic than this presentation indicates. Only two SAR bases appear modest compared to the level of activities of the Russian Navy in the region, and the Concept for Developing the Navy's Search and Rescue System cited here only lists the system's main bases.

The National Guard was created in July $2016 .{ }^{45}$ In October 2016, a new subsystem in the RSChS was also created: the functional subsystem for prevention and liquidation of emergencies of the National Guard. ${ }^{46}$ Due to the novelty of the National Guard and a lack of information about the RSChS subsystem for emergencies of the National Guard, it is difficult to discuss its potential role in Arctic SAR and OSR. ${ }^{47}$ There are just a couple of observations that can be made that may affect SAR and OSR. The Ministry of Internal Affairs, whose interior troops and various special forces were transferred to the National Guard upon its creation, ${ }^{48}$ did not have a functional subsystem equivalent to that created for the National Guard. ${ }^{49}$ SAR for the Ministry of Internal Affairs' vessels used to be among the responsibilities of the Ministry of Defence. ${ }^{50}$ Since the creation of a subsystem that designates that emergencies of National Guard forces are to be handled by the National Guard itself, it is reasonable to assume that this subsystem should now include SAR, and potentially also OSR. Why there is a need for an RSChS functional subsystem for the National Guard, when there was no such need for the Ministry of Internal Affairs, is an open question.

\section{Counterterrorism in the Russian Arctic}

Unlike SAR and OSR, CT has not grown dynamically in tandem with or in response to developments in the Arctic. Arctic counterterrorism is an imposition and the result of a combination of factors external to the region itself. Expansive ambitions of international terrorists play a role here. So does the very nature of counterterrorism, which supports pre-emptively countering terrorism in regions not commonly associated with such a threat. In Russia's case, the country's extensive experience with terrorism speaks to the inclusion of counterterrorism whenever and wherever safety and security is addressed. Also, unlike SAR and OSR, CT is not included in the RSChS. Instead, there is a separate system responsible for fighting terrorism, the national system for counterterrorism (obshchegosudarstvennaya sistema protivodeystviya terrorizmu, OSPT).

\subsection{The National System for Counterterrorism, OSPT}

The OSPT is presented in the Concept on counterterrorism adopted in $2009 .{ }^{51}$ The system consists of the totality of entities that fights terrorism and the normative legal 
acts that regulate their activities. Entities that fight terrorism are federal, regional and local authorities whose competencies include measures to combat terrorism, non-governmental organisations and associations, and citizens who participate in implementing counterterrorist measures of said authorities. The OSPT is organised into two levels: the federal and regional levels. Federal coordination is the prerogative of the National Antiterrorism Committee (NAC). Regional coordination is implemented by antiterrorism commissions in each region (federal subject) that are subordinate to the NAC. The NAC also oversees a Federal Operative Staff as well as regional operative staffs in each region. These coordinating bodies are responsible for resource planning and managing counterterrorist operations. Using the same criteria as when we identified territorial subsystems of the RSChS in the Arctic above, the regions whose antiterrorism commissions and operative staffs cover Russia's Arctic territory are: Murmansk, Arkhangelsk, Nenets, Komi, Yamalo-Nenets, Krasnoyarsk, Sakha and Chukotka (Figure 3). Only here we are not dealing with subsystems, but regional coordination of the OSPT.

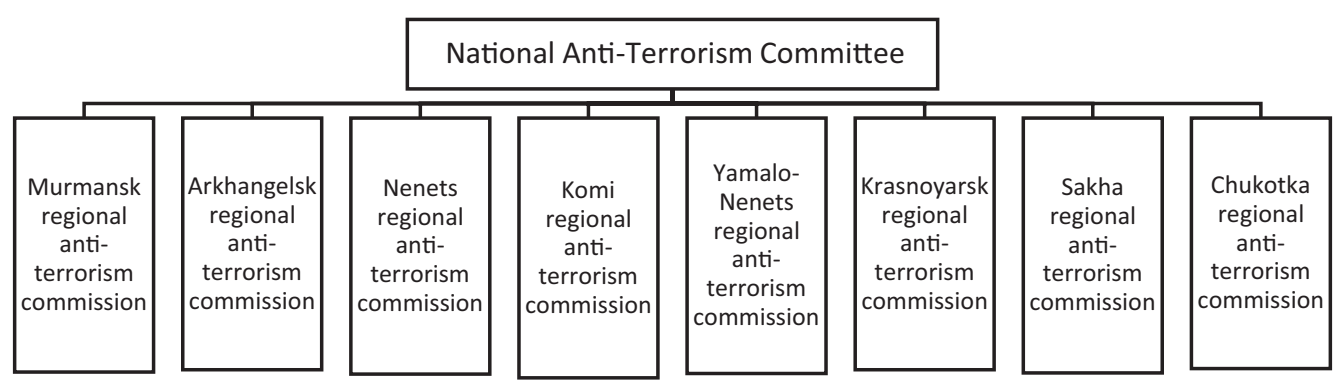

Figure 3. The OSPT's coordinating bodies responsible for the Russian Arctic

Source: Author

The central body in the OSPT is the NAC. This 23 -member-strong body brings together leading officials from a string of different state agencies who all serve ex officio. The NAC is chaired by the director of the Federal Security Service (FSB), who appoints the leader of the Federal Operative Staff. A deputy FSB director serves as deputy NAC chairman, alongside the Minister of Internal Affairs, and leads the NAC Apparatus. Other members include the Minister for Emergencies, the Minister of Transport, the Minister of Defence, and, since December 2016, the Director of the National Guard. ${ }^{52}$ On the regional level, the antiterrorism commissions are chaired by the governors, but the FSB plays a central role on this level too. The heads of the regional FSB branches serve as deputy chairmen in the regional antiterrorism commissions, as well as leaders of the regional operative staffs. The NAC members listed here serve to illustrate considerable overlap in central actors participating in SAR, OSR and CT. 
Counterterrorism shows a flat structure with two levels and adheres to the territorial organisation of state power in the Russian Federation. Decision-making is concentrated in the NAC, and in the hands of the FSB. This structure is almost surprisingly simple, especially in light of the overwhelming complexity of the RSChS, and also the asymmetry of the terrorist threat Russia is faced with today. Terrorist attacks are concentrated in the south of the country, in the North Caucasus. Some have also been carried out in Moscow and other large cities, but most of Russia, including the Arctic, is all but untouched by terrorism. Even so, the OSPT has been fashioned to cover the whole of the Russian Federation, including the Arctic, with a symmetrical structure to coordinate the fight against terrorism. Unlike SAR and OSR, particular challenges have not been addressed by adding layers and specialised subsystems. This is arguably not the result of the task at hand, but rather how it is tackled. One can easily envision a different approach with added layers and specialised subsystems to account for special challenges here as well. The particular challenges posed in the North Caucasus Federal District, which was separated out from the Southern Federal District in 2010, almost beckons the insertion of an interregional level between the federal and regional levels. Instead, the presidential plenipotentiary for the North Caucasus Federal District has been included in the NAC. Thus, particular attention is paid to a particularly challenging area without disrupting the simple logic of the two-level, territorial structure.

The FSB's central role in the OSPT must also be seen in relation to the varied tasks and extensive organisation of this security service. Among FSB's many tasks are controlling the border and providing coastguard services in the Arctic. To carry out these and other tasks, the service has a regional administration in each of Russia's regions, including those in the Arctic, and in many of their municipalities. The FSB is present throughout the Russian state and its bureaucracy, including the Armed Forces where it is tasked with military counterintelligence. ${ }^{53}$ The latter includes an FSB counterintelligence administration in the Northern Fleet.

Whither goes the National Guard? As we saw above, the National Guard was created in 2016 and now commands many of the forces previously under the Ministry of Internal Affairs. The National Guard has been equipped with an extensive portfolio of tasks, including fighting terrorism. ${ }^{54}$ This task in particular has been emphasised as a main objective of the National Guard, both by the service itself and by President Putin. ${ }^{55}$ In December 2016, the director of the National Guard was included among the members in the NAC..$^{56}$ The National Guard did not, however, take over the position of deputy NAC chairman, a post still occupied by the Minister of Internal Affairs. The creation of the National Guard raises more questions than we can answer. Theories about the "true purpose" of this powerful service abound, and fall outside the scope of the current paper. Time will tell whither goes the National Guard. The many unknowns surrounding this fresh addition to Russia's already densely populated security and intelligence sector fuels concerns that there is a potential "turf war" on the horizon. Such an eventuality could have adverse effects 
on coordination of the OSPT in the short term, and for the FSB's leading position in Russian counterterrorism in the long term.

\section{The Architecture of Emergency Preparedness in the Russian Arctic}

On the face of it, interrelations between SAR and OSR make our work easier by there being only two systems to compare and include in the architecture of Arctic emergency preparedness: the RSChS and the OSPT. The complexity of the RSChS quickly quells any such optimism, however. Rather than one system for SAR and OSR, we are in reality dealing with 15 systems: eight territorial subsystems that cover the Arctic and seven functional subsystems that either have SAR or OSR as their targeted function or where such activities are included in broader portfolios. Are we best served considering the architecture of Arctic emergency preparedness as made up of $1+1$ structures, the RSChS and the OSPT? Or should we consider the architecture of Arctic emergency preparedness as made up of $15+1$ structures, adding up the subsystems in the RSChS plus the OSPT? This choice greatly affects the architecture of Arctic emergency preparedness.

Let us first approach the problem with optimism and consider the architecture of Arctic emergency preparedness as a composite structure that brings together two systems, the RSChS for SAR and OSR and the OSPT for CT. Figure 4 shows how the RSChS and the OSPT compare in terms of how vertical/horizontal their structures are, whether they are territorially or functionally organised, and how centralised/ decentralised their decision-making is. The final column in Figure 4 categorises the resulting architecture of emergency preparedness according to the categories in Harrison and Klein's diversity typology.

\begin{tabular}{|c|c|c|c|}
\hline & $\begin{array}{l}\text { RSChS } \\
\text { structure }\end{array}$ & OSPT structure & $\begin{array}{l}\text { Emergency preparedness } \\
\text { architecture }\end{array}$ \\
\hline Vertical/horizontal organisation & $\begin{array}{l}\text { Tall } \\
\text { (5 levels) }\end{array}$ & $\begin{array}{l}\text { Flat } \\
\text { (2 levels) }\end{array}$ & Maximum separation \\
\hline $\begin{array}{l}\text { Territorial or functional } \\
\text { organisation }\end{array}$ & $\begin{array}{l}\text { Territorial and } \\
\text { functional }\end{array}$ & Territorial & Moderate variety $^{\dagger}$ \\
\hline $\begin{array}{l}\text { Decision-making in the } \\
\text { organisation }\end{array}$ & Various actors & NAC & Maximum disparity \\
\hline
\end{tabular}

Figure 4. The Architecture of Emergency Preparedness in the Russian Arctic (I)

${ }^{\dagger}$ Moderate variety is not a valid category when comparing two units on a categorical attribute.

Source: Author.

The RSChS has a tall structure with five levels, whereas the OSPT has a flat structure with two levels. This makes diversity within the architecture of Arctic emergency preparedness along the vertical-horizontal continuum a case of maximum separation. According to Harrison and Klein, homogeneity on a lateral continuum is often predicted to be beneficial, and the occurrence of homogeneity is more important 
than where on the continuum it occurs. A high degree of separation on the other hand, is associated with low cohesion and poor performance..$^{57}$

As for variety on the categorical attribute of territorial or functional organisation, the complex organisation of the RSChS with both territorial and functional subsystems causes some problems. In an "ideal world", we would have a dyad on our hands which could per definition produce either minimum or maximum variety. ${ }^{58}$ We are therefore faced with the "incorrect" result of a dyad that displays overlap in the categorical attribute. Such overlap is a characteristic associated with moderate variety, a category that can only exist when we consider more than two units. This points us in the direction of considering the RSChS as an association of multiple systems rather than as one system. Whilst "incorrect" in the present analysis, moderate variety is a potentially positive attribute, as it can lead to greater creativity and productivity, higher decision quality and increased flexibility. Moderate variety can also incur challenges such as problems with information sharing. ${ }^{59}$

In terms of decision-making, this is decentralised in the RSChS with a number of actors vested with significant decision making (the Main Directorates of MChS for the regions, Rosmorrechflot, Rosaviatsiya, and the Navy's General Staff). In the OSPT decision-making is centralised in the FSB-dominated National Antiterrorism Committee. Considering decision-making as a valued and desired resource, the NAC enjoys an enviable position within the architecture. Maximum disparity arises precisely when one member outranks all others in terms of the desired resource. A high degree of disparity can lead to reduced performance as a result of within unit competition, suppression of creativity, withdrawal and interrupted flows of information. ${ }^{60}$

Overall, the architecture of Arctic emergency preparedness as made up of the RSChS and the OSPT shows significant potential challenges to comprehensive emergency preparedness in the Arctic. The task of assessing this architecture is, as we have seen, complicated by the structural asymmetry between the RSChS and the OSPT. The RSChS is a collection of systems, some of them territorial and others functional. Considering the size and complexity of the RSChS, it appears as an artificial simplification to compare the RSChS and the OSPT one-to-one as shown in Figure 4. Even though the OSPT is not part of the RSChS, the OSPT does resemble the functional subsystems in the RSChS. According to the logic of the RSChS, the OSPT could have been included in this "super-system" on par with the functional subsystems. Assessing the architecture as a result of the RSChS-OSPT dyad arguably oversimplifies the topic and places unwarranted weight on the OSPT (in addition to the analytical challenge of the two systems showing a distorted form of moderate variety on our categorical attribute). To correct this skewness, we will look at the architecture of Arctic emergency preparedness as a superstructure made up of 16 systems: the OSPT, the seven functional subsystems in the RSChS that handle SAR and OSR, and the eight territorial subsystems in the RSChS that cover the Russian Arctic (Figure 5). 


\begin{tabular}{|c|c|c|c|}
\hline $\begin{array}{l}\text { Emergency preparedness } \\
\text { system }\end{array}$ & $\begin{array}{l}\text { Vertical/horizontal } \\
\text { organisation }\end{array}$ & $\begin{array}{l}\text { Territorial or } \\
\text { functional organisation }\end{array}$ & $\begin{array}{l}\text { Decision-making in the } \\
\text { organisation }\end{array}$ \\
\hline OSPT & $\begin{array}{l}\text { Flat } \\
\text { (2 levels) }\end{array}$ & Territorial & NAC \\
\hline $\begin{array}{l}\text { SAR in internal waters and } \\
\text { territorial sea }\end{array}$ & $\begin{array}{l}\text { Tall } \\
\text { (5 levels) }\end{array}$ & Territorial & Rosmorrechflot \\
\hline SAR at sea & $\begin{array}{l}\text { Flat } \\
\text { (2 levels) }\end{array}$ & Territorial & Rosmorrechflot \\
\hline OSR at sea & $\begin{array}{l}\text { Moderate } \\
\text { (3 levels) }\end{array}$ & Territorial & Rosmorrechflot \\
\hline OSR in internal waterways & $\begin{array}{l}\text { Moderate } \\
\text { (3 levels) }\end{array}$ & Territorial & Rosmorrechflot \\
\hline SAR for civil aviation & $\begin{array}{l}\text { Moderate } \\
\text { (3 levels) }\end{array}$ & Territorial & Rosaviatsiya \\
\hline $\begin{array}{l}\text { Armed Forces of the } \\
\text { Russian Federation }{ }^{\star}\end{array}$ & $\begin{array}{l}\text { Moderate } \\
\text { (4 levels) }\end{array}$ & Territorial & Navy General Staff \\
\hline National Guard ${ }^{\star \star}$ & $?$ & ? & ? \\
\hline Murmansk Region & $\begin{array}{l}\text { Moderate } \\
\text { (3 levels) }\end{array}$ & Functional & $\begin{array}{l}\text { Main Directorate } \mathrm{MChS} \text { for } \\
\text { Murmansk }\end{array}$ \\
\hline Arkhangelsk Region ${ }^{\star \star \star}$ & $\begin{array}{l}\text { Moderate } \\
\text { (3 levels) }\end{array}$ & Functional & $\begin{array}{l}\text { Main Directorate } \mathrm{MChS} \text { for } \\
\text { Arkhangelsk }\end{array}$ \\
\hline Nenets Region ${ }^{\star \star \star}$ & $\begin{array}{l}\text { Moderate } \\
\text { (3 levels) }\end{array}$ & Functional & $\begin{array}{l}\text { Main Directorate } \mathrm{MChS} \text { for } \\
\text { Nenets }\end{array}$ \\
\hline Yamalo-Nenets Region ${ }^{\star \star \star}$ & $\begin{array}{l}\text { Moderate } \\
\text { (3 levels) }\end{array}$ & Functional & $\begin{array}{l}\text { Main Directorate } \mathrm{MChS} \text { for } \\
\text { Yamalo-Nenets }\end{array}$ \\
\hline Komi Region $^{\star \star \star}$ & $\begin{array}{l}\text { Moderate } \\
\text { (3 levels) }\end{array}$ & Functional & $\begin{array}{l}\text { Main Directorate } \mathrm{MChS} \text { for } \\
\text { Komi }\end{array}$ \\
\hline 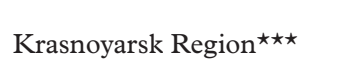 & $\begin{array}{l}\text { Moderate } \\
\text { (3 levels) }\end{array}$ & Functional & $\begin{array}{l}\text { Main Directorate } \mathrm{MChS} \text { for } \\
\text { Krasnoyarsk }\end{array}$ \\
\hline Sakha Region ${ }^{\star \star \star}$ & $\begin{array}{l}\text { Moderate } \\
\text { (3 levels) }\end{array}$ & Functional & $\begin{array}{l}\text { Main Directorate } \mathrm{MChS} \text { for } \\
\text { Sakha }\end{array}$ \\
\hline Chukotka Region ${ }^{\star \star \star}$ & $\begin{array}{l}\text { Moderate } \\
\text { (3 levels) }\end{array}$ & Functional & $\begin{array}{l}\text { Main Directorate MChS for } \\
\text { Chukotka }\end{array}$ \\
\hline $\begin{array}{l}\text { Emergency preparedness } \\
\text { architecture }\end{array}$ & $\begin{array}{l}\text { Moderate } \\
\text { separation }\end{array}$ & Moderate variety & Moderate disparity \\
\hline
\end{tabular}

Figure 5. The Architecture of Emergency Preparedness in the Russian Arctic (II)

*This represents the Navy's SAR system, which is a subsystem in the functional subsystem for emergencies of the Armed Forces of the Russian Federation in the RSChS.

${ }^{\star \star}$ Missing values marked with "?".

$\star \star \star$ Extrapolated based on the emergency system in the Murmansk Region. Source: Author.

Figure 5 lists the 15 territorial and functional subsystems in the RSChS presented in section 3 alongside the OSPT, and categorises the resulting architecture of emergency preparedness according to the categories in Harrison and Klein's diversity typology. (For presentational purposes Figure 5 is inverted compared to Figure 4 with the organisational principles in the columns and the many structures in the rows.) Figure 5 shows the diversity within the RSChS and allows for a more finetuned comparison of the SAR, OSR and CT structures. A necessary consequence is 
that the relative weight of the OSPT within the architecture drops from $1 / 2$ to $1 / 16$. In practice, the comparison is of 15 systems including the OSPR as the values for the system pertaining to the National Guard are missing.

Among the 15 systems, there are flat, moderate and tall structures. This means that diversity within the architecture of Arctic emergency preparedness along the vertical-horizontal continuum is a case of moderate separation. Most of the systems have moderate structures with three levels (11 systems) or 4 levels (one system). Two systems have flat structures with 2 levels, and just one system has a tall structure with five levels. Diversity as separation on the vertical/horizontal continuum was grossly over-reported in Figure 4 as the five-level structure of the RSChS has only fully been adopted in one of its subsystems. According to Harrison and Klein, investigators of diversity as separation posit that greater similarity -- reduced separation -- yields higher levels of cooperation. ${ }^{61}$

Turning now to our categorical attribute of territorial and functional organisation and the degree of variety, the architecture of emergency preparedness shows moderate variety with substantial overlap in some, but not all, of the components. As we saw above, moderate variety can incur challenges such as problems with information sharing, but it is also associated with many positive predicted outcomes, such as greater creativity and productivity, higher decision quality and increased flexibility. ${ }^{62}$

When it comes to decision-making, the architecture of Arctic emergency preparedness presented in Figure 5 shows several central decision-makers including the Main Directorates of the MChS, central bodies under the Ministry of Transport (Rosmorrechflot and Rosaviatsiya), the Navy's General Staff and NAC. This moves the analysis away from an overestimation of NAC's role as a decision-making body within the architecture, and rightly places it among several important decision-making bodies involved in SAR, OSR and CT. Moderate disparity of the desired resource reduces the potential for negative effects such as withdrawal and interrupted flows of information. ${ }^{63}$

Structural potential for developing comprehensive emergency preparedness in the Russian Arctic appears more favourable when we consider the architecture of Arctic emergency preparedness as the composite structure made up of the subsystems in the RSChS plus the OSPT. In theory, there is opportunity for cooperation and flexibility in this architecture. There is also potential for competition within the architecture, which can improve or weaken performance. There is still some potential for withdrawal or interrupted flows of information among those in the architecture. We cannot, however, disregard the empirical fact that a vast number of emergency preparedness systems have been "rounded up" in the RSChS, and the OSPT has not been included. Nor should we disregard the potential for separation, variety and disparity inherent in the list of (sub)systems in Figure 5 that fall beyond the scope of the current analysis. Neither in Figure 4 nor in Figure 5 do we find even a single instance of minimal separation, variety or disparity. In other words, the architecture of emergency preparedness in the Russian Arctic is rife with differences, both in kind and in degree, rather than similarities. 


\section{Conclusions}

Activity in the Arctic has increased over the past few decades and is projected to increase further in future. More activity in the region, and more varied activity, necessitates improvements in Arctic emergency preparedness. This need for improved emergency preparedness pertains to both traditional and untraditional emergency preparedness fields. SAR and OSR have long been on the agenda for improving the safety of people and the environment in the Arctic as activity in the region grows. Lately, CT has also joined the agenda as a result of the abundance of strategic resources in the Arctic, the expanding threat posed by terrorist organisations, and recognition that the latter may target the former.

This paper has examined the formal institutional foundation for a comprehensive emergency preparedness system in the Russian Arctic through a comparative analysis of SAR, OSR and CT structures. The main conclusion of the paper is that the current organisation of these three fields poses a significant obstacle to tackling SAR, OSR and CT challenges comprehensively. This conclusion rests on the fact that there are wide discrepancies among the many emergency systems involved in SAR, OSR and CT in the Russian Arctic, and that correlation and coordination among these systems are either lacking or wanting. Furthermore, most of these systems are also faced with coordination challenges of their own, which aggravates challenges to potential inter-system coordination.

SAR and OSR activities are organised into multiple systems. Additionally, there is an emergency system specific to the Armed Forces (and potentially an emergency system specific to the National Guard) that also includes SAR and OSR activities. This system, which is also a functional subsystem in the RSChS, is managed by the Ministry of Defence and includes the Navy's own SAR system; effectively making Navy SAR a functional sub-subsystem in the RSChS. While the importance of coordination among these systems and the various actors involved in SAR and OSR activities is acknowledged, regulation on such coordination is insufficient.

CT activities are united in one system, the OSPT, which is not part of the RSChS. Although CT activities, much like SAR and OSR activities, involve many and varied actors; the organisation of the OSPT is streamlined and simple. Coordinating bodies on the federal and regional levels reflect Russia's federal structure. The most central positions in the OSPT's coordinating bodies are occupied by the FSB. Leaving the potential challenge to FSB leadership posed by the National Guard aside; as yet, the leading role of the FSB in the OSPT's coordinating bodies provides clear lines of responsibility in this field.

The two traditional emergency preparedness fields have in common that they make particular provisions for the Arctic. The OSPT, on the other hand, is a symmetrical system across the Russian Federation. Provisions for the Arctic within the various SAR and OSR systems contribute to the variance among these systems. Despite the abundance of relevant emergency preparedness systems and their provisions for the 
Arctic, the literature available raises questions about the adequacy of SAR and OSR preparedness in the region. The symmetrical organisation of the OSPT does not make provisions for any challenges that may be specific to the Arctic. Since the Russian Arctic is relatively untouched by terrorism as compared to other parts of Russia, the symmetry in the organisation of CT arguably ensures more adequate preparedness in this region than any organisation making provisions for terrorist threats would.

Making use of the diversity typology developed by Harrison and Klein, we were able to synthesise the structure and potential outcomes of the architecture of emergency preparedness in the Russian Arctic. Due to the significant asymmetries between the RSChS and the OSPT, we made two versions of this architecture with highly different results. By merging the RSChS and the OSPT, the resulting architecture showed maximum separation along the vertical/horizontal continuum, maximum disparity in decision-making and produced an analytically impossible result for territorial or functional organisation. Such a superstructure would, in theory, be associated with mainly negative outcomes, such as low cohesion and poor performance. By considering the architecture as a superstructure made up of 16 systems ( 15 in practice) the result was moderate separation, variety and disparity across the three variables. Such an architecture has, in theory, potential for cooperation, flexibility and high decision quality. This does show considerable potential for a well-functioning emergency preparedness architecture, but must be tempered by the fact that we are talking about moderate diversity of various types, and not about similarities.

Based on the discussion in this paper, I posit that the two main obstacles to comprehensive emergency preparedness in the Russian Arctic today, from a structural perspective, is the impenetrable complexity of Arctic SAR and OSR and the isolation of CT in Russia's emergency preparedness. A potential window of opportunity for cooperation among the different systems despite these structural obstacles is the fact that many of the most central actors are involved in all three emergency preparedness fields. Looking past the horizon of the current paper, I would venture to posit that these observations are significant beyond the scope of developing comprehensive emergency preparedness in the Russian Arctic, as they also shape the potential for international endeavours to improve emergency preparedness in the Arctic.

\section{Acknowledgements}

This research was conducted within the framework of the international research project Maritime Preparedness and International Partnership in the High North (MARPART).

\section{End Notes}

1. "Fundamentals of the Russian Federation's State Policy in the Arctic for the Period to 2020 and Further Prospects" [Russian], (2008), section iii, article 6-a and section vi, article 11-c. 


\section{The Arctic in Russia's Emergency Preparedness System}

2. Ibid., section vi, article 11-b.

3. Ibid., section iv, article 8-a.

4. Kremlin, "Security Council Meeting on Implementing State Policy in the Arctic" [Russian], (2014), URL: http://www.kremlin.ru/events/president/news/20845 [31.05.2017].

5. See for example: Gal Luft and Anne Korin, “Terror's Next Target”, The fournal of International Security Affairs (2003, December), URL http://www.iags.org/n0111041.htm [09.01.2018].

6. Kremlin, op. cit.

7. RT, "Russian security chief urges stronger anti-terror defense for Arctic" (2015, 11 August). URL: https://on.rt.com/6ovv [12.08.2015].

8. Ibid.

9. For a discussion of counterterrorism in the Russian Arctic including exercises see: Ingvill Moe Elgsaas, "Counterterrorism in the Russian Arctic: Legal Framework and Central Actors" [Russian], Arctic and North 29 (2017).

10. David Harrison and Katherine Klein, "What's the difference? Diversity constructs as separation, variety, or disparity in organizations", Academy of Management, 32:4 (2007): 11991228.

11. Ibid. Especially Table 1, 1203.

12. Presidential decree No 296 of 2 May 2014, "On the Land Territories of the Arctic Zone of the Russian Federation" [Russian].

13. Governmental resolution No 366 of 21 April 2014, "On approval of the state programme of the Russian Federation 'Socio-economic development of the Arctic zone of the Russian Federation"” [Russian]. In 2017, the time limitation "until 2020" was excluded.

14. Federal law No 68 of 21 December 1994, "On Protecting the Population and Territory from Natural and Man-made Emergencies” [Russian]: article 4.

15. Ibid., articles 4 and 4.1 .

16. Main Directorate of MChS Russia for the Murmansk Region, "Competencies, tasks and functions [Russian], URL: http://51.mchs.gov.ru/folder/318631 [20.11.2017].

17. I wanted to include a tabular overview of the different bodies operating under the auspice of the Main Directorate. This proved impossible as the table covered some 10 pages before it was even completed. So instead, I here present some observations I made while scouring through the organisational presentations available on the Main Directorate's webpages starting with "Forces and resources" [Russian], URL: http://51.mchs.gov.ru/resources [20.11.2017] and proceeding to the presentations under each of the 13 forces and resources listed.

18. Main Directorate of MChS Russia for the Murmansk Region, "Territorial fire and rescue garrison of the Murmansk Region” [Russian], URL: http://51.mchs.gov.ru/folder/1319978 [20.11.2017].

19. Government of the Russian Federation, "List of functional subsystems of federal executive bodies and authorized organizations in the unified state system for preventing and eliminating emergencies" [Russian], (2003). Supplemement to Provision on the RSChS.

20. Ministry for Emergencies order No 480 of 22 July 2013, "On the Approval of the Provision on the Functional Subsystem for Coordination of Search and Rescue of People in Internal Waters and the Territorial Sea of the Russian Federation of the Unified State System for Preventing and Eliminating Emergency Situations" [Russian].

21. Ministry for Emergencies. (2017b). Territorial Bodies [Russian]. URL: http://www.mchs. gov.ru/ministry/territorial [1 June 2017 2017].

22. Ministry for Emergencies, "Search and Rescue Service" [Russian]. URL: http://www.mchs. gov.ru/dop/sily/Poiskovo_spasatelnaja_sluzhba [01.06.2017]. 


\section{Ingvill Moe Elgsaas}

23. The Arctic, "Rogozin: Four out of ten Arctic emergency rescue centers now operational" (2016), URL: http://arctic.ru/infrastructure/20160930/451391.html [02.06.2017].

24. Lassi Heininen, Aleksander Sergunin, and GlebYarovoy, "Russian Strategies in the Arctic: Avoiding a New Cold War", Valdai Discussion Club (2014): 69, URL: http://www.uarctic.org/ media/857300/arctic_eng.pdf [07.08.2018].

25. Government of the Russian Federation, op.cit.

26. Ministry of Transport order No 169 of 26 November 2007 "On Approving the Provision on the Functional Subsystem Organising and Coordinating Search and Rescue Services (both Russian and Foreign) when Searching and Rescuing People and Ships in Distress at Sea within Search and Rescue Areas of the Russian Federation's Unified State System for the Prevention and Liquidation of Emergency Situations" [Russian] and Ministry of Transport order No 53 of 6 April 2009 "On Approving the Provision on the Functional Subsystem Organising the Prevention and Liquidation of Oil Spills at Sea from Ships and Objects Regardless of their Departmental and National Belonging" [Russian].

27. Ibid.

28. Gosmorspassluzhba, "Branches" [Russian], URL: http://morspas.com/ [02.10.2017].

29. Ministry of Transport order No. 19 of 5 February 2016 "On approving the Provision on the functional subsystem for organising activities on the prevention and liquidation of oil and petroleum spills in internal waterways from ships and sea and river transport facilities in the unified state system for the prevention and liquidation of emergency situations" [Russian].

30. Ibid.

31. Svetlana Kuznetsova, Ivan Saveliev, and Maxim Zadorin, "Russia", ed. Ingvill Elgsaas and Kristine Offerdal, "Maritime preparedness systems in the Arctic- institutional arrangements and potential for collaboration" MARPART ProjectReport 3 (Nord University, 2018). Alexei Bambulyak, Are Kristoffer Sydnes and Maria Sydnes, "Oil-spill response in the Russian Arctic", ed. Leif Christian Jensen and Geir Hønneland, "Handbook of the Politics of the Arctic" (Cheltenham, UK, Northampton, MA, USA, Edward Elgar Publishing, 2015): 76.

32. Alexei Bambulyak, Are Kristoffer Sydnes and Maria Sydnes, op. cit.: 81 .

33. Viktor Ilyukhin, "On Developing Russia's Maritime SAR System" [Russian] (Neptun, 2014), URL: http://neptunworld.com/2014/04/o-razvitii-sistemy-poiskovo-spasatelnogo-obespecheniya-morskoj-deyatelnosti-rossii/ [17.08.2017].

34. Viktor Ilyukhin, "Normative and Legal Aspects of Maritime Search and Rescue in the Russian Arctic”. [Russian] Arctic: Ecology and Economics, 1:17 (2015): 78.

35. Government resolution No 834 of 26 August 1995, "Plan for Cooperation among Federal Executive Bodies when undertaking Search and Rescue Activities at Sea and in Water Basins of the Russian Federation" [Russian].

36. Alexei Bambulyak, Are Kristoffer Sydnes and Maria Sydnes, op. cit.: 69 and Table 4.2.

37. Government of the Russian Federation, "Provision on the unified system for aerospace search and rescue in the Russian Federation" [Russian], (2007): article 4. Supplemement to Resolution No 538 of 23 August 2007.

38. Rosaviatsiya, "SAR Formations (by ES AKPS zone)" [Russian]. URL: http://www.favt. $\mathrm{ru} /$ dejatelnost-poisk-i-spasanie-struktura-es-akps-poiskovo-spasatelnye-formirovanija/ [30.09.2017].

39. Government of the Russian Federation, (2007), op.cit., articles 7 and 10.

40. On the federal level, Rosaviatsiya's Commission for the Prevention and Liquidation of Emergencies and Fire Safety is responsible for coordination, Rosaviatsiya is the standing body and day-to-day management is carried out by the Main Aviation Coordination Centre for SAR. On the regional level, Rosaviatsiya's territorial bodies' commissions for the prevention and liquidation of emergencies and fire safety are responsible for coordination, the regional branches are the standing bodies and day-to-day management is carried out 
by aviation coordination centres for SAR. On the object level, airport commission for the prevention and liquidation of emergencies and fire safety are responsible for coordination, authorised airport units are the standing bodies and day-to-day management is carried out by airport dispatch units. Ministry of Transport, "Provision on the functional subsystem for search and rescue services for civil aviation flights of the unified state system for preventing and eliminating emergencies" [Russian], (2012): article 3.

41. Government of the Russian Federation, op. cit. (2003).

42. Viktor Ilyukhin, op. cit. (2015): 79.

43. Ministry of Defence, "Concept for Developing the Navy's Search and Rescue System for the period up to 2025” [Russian], (2013).

44. Ibid., section iv, article 17.

45. Presidential decree No 157 of 5 April 2016 "Questions concerning the Federal Troops of the National Guard of the Russian Federation" [Russian].

46. Government resolution No 1064 of 19 October 2016 "On introducing changes in the supplement to the provision on the state system of prevention and liquidation of emergency situations" [Russian].

47. Apart from a news release on the MChS webpage simply reiterating the inclusion of the National Guard's functional subsystem in the RSChS there are no details on this subsystem that are publicly available. Ministry for Emergencies, "Rosgvardiya [the National Guard] Included in the List of Functional Subsystems for Prevention and Liquidation of Emergencies” [Russian]. URL: http://central.mchs.ru/news/item/806197/ [16.08.2017].

48. Aleksey Nikolsky, "Russia's New National Guard: Foreign, Domestic and Personal Aspects", Moscow Defense Brief, 2 (2016): 16-17.

49. The Ministry of Internal Affairs was and still is responsible for an RSChS functional subsystem to uphold public order. Government of the Russian Federation, (2003), op.cit.

50. Viktor Ilyukhin, op. cit. (2015):79.

51. "Concept on Countering Terrorism in the Russian Federation" [Russian], (2009), section ii.

52. Presidential decree No 1258 of 2 September 2012 "On Approving the Composition of the National Antiterrorism Committee and Ammendments to Presidential Decree of February 152006 No 116 "On Countering Terrorism" and the Composition of the Federal Operative Staff Approved by that Decree" [Russian].

53. Agentura, "Territorial bodies of military counterintelligence" [Russian] URL: http://www. agentura.ru/dossier/Russia/fsb/structure/osobist/uvkrs/ [08.01.2018].

54. Russian federal law No 226 of 3 July 2016 "On the Troops of the National Guard of the Russian Federation" [Russian], chapter 1, article 2.1-3.

55. National Guard, "The National Guard's Main Task is to Fight Terrorism and Ensure Public Safety for Russia's Citizens” [Russian], (2016), URL:http://rosgvard.ru/klyuchevaya-zadacha-rosgvardii-borba-s-terrorizmom-i-obespechenie-obshhestvennoj-bezopasnosti-rossijskih-grazhdan/ [22.03.2017]. The Moscow Times, "Putin Announces Establishment of Russian National Guard", (2016), URL: https://themoscowtimes.com/news/putin-announces-establishment-of-russian-national-guard-52400 [29.06.2017]

56. Presidential decree No 657 of 7 December 2016 "On Alterations and Annullments of Selected Acts of the President of the Russian Federation" [Russian].

57. Harrison and Klein, op. cit.: 1203-1204.

58. Ibid., 1205.

59. Ibid., 1203 and 1205.

60. Ibid., 1206-1207.

61. Ibid., 1204.

62. Ibid., 1203 and 1205 .

63. Ibid., 1206-1207. 